\title{
Defined Activity Status Date
}

National Cancer Institute

\section{Source}

National Cancer Institute. Defined Activity Status Date. NCI Thesaurus. Code C93758.

The date (and time) on which the status is assigned to the activity. 